\title{
Effectiveness of Financial Market as Economic Development Agents in Africa
}

\author{
Akinyele Akinwumi Idowu \\ Department of Banking and Finance, \\ Federal Polytechnic Ede Osun State \\ Bosede Comfort Olopade \\ Department of Economics, \\ Adeleke University Ede. Osun State \\ Oluwayemisi K. Adeleke \\ Department of Economics, \\ Redeemers University Ede. Osun State \\ Nureni Adekunle Lawal \\ Department of Management and Accounting Science \\ Ladoke Akintola University of Technology Ogbomosho, Osun State
}

\begin{abstract}
The development in Africa's financial sector in recent years has been remarkable. Though relatively underexplored and underinvested sector a mere decade ago, today, this sector is considered to be one of the continent's brightest prospects. This is due to the fact that for some time now, financial sector development has been on front burners in the economic agenda of most African countries. This sector has the potential to transform the lives of millions of people across the continent. Low rate of economic development has created a lot of social stress in Africa, which is responsible for incidence and prevalence of poverty, and consequent social uprisings on a number of occasions. Various studies have examined the role of African financial market development on economic growth, but none have strictly generated a combined focus on the three major African groupings - the Southern, the Western and the Eastern African regions. This paper specifically address this void and it examines the determinant and impact of banking sector and stock market development on Africa's economic growth and development. Various econometric techniques that include descriptive statistics, unit root tests and OLS were used to analyse data. The study finds out that local financial markets play crucial roles in economic development of Africa, albeit in varying magnitude. The study also observes that banking sector development and economic growth promote stock market development. In addition, this paper finds an interesting result in the fact that trade openness has a negative impact on stock market development, which is different from the findings of many other studies. Financial market size is also strongly related to the size of the economy. This paper has some policy implications. In order to promote banking and stock market development in the region, it is important to encourage savings by appropriate incentives, consider the possibility of one single currency for African countries in order to improve stock market liquidity and develop financial intermediaries. This paper shows an in-depth analysis of Africa financial markets in order to assess how they can improve and benefit the global investor. In addition, it is found that financial intermediaries and stock markets are complements rather than substitutes in the growth process.
\end{abstract}

Keywords: Economic-development; financial-markets; financial-intermediary; Capitalmarkets; Stock-markets; Banking-sector. 


\section{INTRODUCTION}

The most prominent financial institution in African countries are the banks. They are primly strategically located for commercial activities. Only few African countries operate efficient capital markets and most tend to rely primarily on commercial banks for finance. As finance is fulcrum upon which economy generally revolves, a country's economy is only as strong as the size of her financial market. However, the banking sectors of most African countries, do not yet have sufficient depth to play a catalytic role in promoting the development of a deep financial sector. When compared to the rest of the world, most standard indicators of banking sector depth are low. Total volume and value of asset is low and credit to the private sector is limited. In many countries, there is deficiency in legal and regulatory structures, this has grave consequence for creditor protection. Generally, the level of economic development is low. Both the banking sector and capital market activities will be minimal both in volume and value relative to other advanced regional economies. This suggests that some countries may be too small to develop viable financial markets even with appropriate macroeconomic policies and institutions, leading to calls for regional equity markets and multi-exchange listing to help overcome scale constraints.

There are at least 18 stock exchanges in the region. However, most of these have been largely inactive. Most Sub-Saharan African countries do not yet operate a viable stock market. With few exceptions, these markets can be described as having few company listings, low market capitalisation and low liquidity. The Johannesburg Stock Exchange (JSE) in South Africa is the obvious exception. In 2008, the JSE accounted for nearly $85 \%$ of Africa's total market capitalisation. Although the size of the other African exchanges varies, in general they are small relative to markets in the rest of the world. Most African exchanges are also relatively illiquid compared to those in other regions; Sub-Saharan exchanges had an average turnover ratio of $10 \%$ compared to $50 \%$ in emerging Asian economies and actual number of trades is still very low. Such low levels of activity make it difficult to attract the volume of participation necessary to enlarge and deepen markets. This can be partly explained by the fact that during the last two decades many African countries relied on easy access to concesssional finance - access which impeded internal innovative financial growth and development, and led to debt profiles dominated by foreign currency (Blommestein and Horman, 2007).

There is no doubt that Stock Exchange plays a vital and varied roles in capital formation and the economic development of most African Countries. A review of their roles and activities included the following:

(i) They assisted listed companies to raise required equity capital and adjust organization capital structure as they found necessary and appropriate, in order to take on available business opportunities, acquire needed assets, and thereby foster growth.

(ii) Takes care of moral hazards, adverse selection and information asymmetry on behalf of investors and listed companies.

(iii) Providing Government, companies and investors with investment opportunities in listed securities.

(iv) This is an effective tool in the fight against inflation. The capitalization of companies in the market is increasing, which stimulates economic growth.

(v) Organizations are becoming stronger and can act much more confidently, because of the offered investors' protection via formal oversight and regulation of investments. The general state of the economy is stabilizing.

(vi) It is easier to identify a viable business for investment, and small investors to participate in the growth and future wealth of profitable companies. Entrepreneurs can have access to long-term funds. 
Normally stock exchange aids economy liquidity, however, there is lack of liquidity on the African stock exchanges which can be attributed to a number of factors including the limited number of listed companies, the limited free float, the low numbers of retail investors, significant and long-term holdings of securities and the high transaction costs on the stock exchanges. This makes it difficult for prospective investors to find required quantum, and foreign or institutional investors who want to divested may not have buyers of meaningful quantities and value.

Africa's financial markets are generally immature and are widely characterized by their low level of activity and the domination of the banking sector. It is possible to overcome these constraints by promoting regional integration. Thinking about sovereignty would inhibit this kind of reform and if found absolutely there is need to be cautious to go slowly. Immediate reforms can however be envisaged.

Efficient, well-regulated financial markets mobilise capital and channel resources into productive investments. They also help to manage and diversify risk, as well as monitor the corporate sector financial deals. With this in mind, increasing attention has been paid to developing and deepening financial markets in African countries over the last decade. National development strategies have included plans to create new markets or augment existing ones, and both multilateral and bilateral donors have supported such efforts.

Apart from South Africa, equity markets in Sub-Saharan Africa are small and illiquid, the character of each domestic financial sector - and indeed all aspects of each economy - varies across countries, but many have immature domestic capital markets and rely on relatively banking sectors. The low development level of financial markets is not surprising, increasing evidence suggests that the size of a financial market is related to the size of its economy. Given the small size of the majority of African economies, efforts to further integrate capital markets, in particular by promoting cross-border listings and sharing of technologies, are relevant, especially various reforms to improve the efficiency of the banking sector, capital market and the legal and regulatory environments.

\section{Research Problem}

Management of finance and related policies are very sensitive issues that cannot be left to the mediocre. Its management cannot be handled with levity otherwise it will spell doom for Economic growth and development. The issue is how sensitive and responsive to development is the financial system. How prepared, exposed and developmental oriented are her managers such that they can be proactive to events within and around them in order to take advantage of emerging or unfolding opportunities and maximize it for National economic growth and development. Concerned as Africa continent is on the quest for economic prestige and despite the establishment of the commercial banks and the stock exchanges, Africans still decry inadequate capital for investment and consequent low Gross Domestic Product (GDP) which were the core issues that the establishment commercial banks and capital market were conceived to address. The financial deepening and inclusion experienced even in rural areas of developed economy is still a mirage to us. Africa has not being able to tap fully the natural resources that she is blessed with as it should. There are numerous agencies/sectors involved in economic development, but of all the sectors that stimulate economic growth and development in Africa, the commercial banks and the Stock Exchanges stand out. This research work is aimed at identifying the contributions that commercial banks and the Stock Exchange have made to the development of the African economy and how they affect one another. 


\section{Objectives and Hypotheses}

The main objective of this study is to investigate the contributions of the financial market (stock market and banking sector) to the economic development of the African states. The study traced the link between banking sector development, stock market development and economic development among African states. It hypothesized that stock market size and banks' lending activities does not affects the size of the economic development.

\section{Research Questions}

(1) What role does stock market liquidity play in African states economic development?

(2) In which ways does financial market size affect the size of the economy?

(3) How do we effect collaboration and trade openness on African states financial market?

(4) How does banking sector and stock market development promote economic growth?

\section{Significance of Study}

This paper has some policy implications. In order to promote banking and stock market development in the region, it is important to encourage savings mobilization, encourage and improve stock market liquidity. To develop financial intermediaries and to control inflation African states must encourage politically stable and business friendly environment. This will likely encourage foreign direct investment even on our banking sector and stock exchange trading floors.

\section{THEORETICAL REVIEW}

This study is premised on three theories: Financial repression theory, Shaw hypothesis and the Modern growth theory.

\section{The theory of financial repression}

This theory is traced back to the works of Schumpeter (1982), which posits that efficient utilization of resources via a highly organized, developed and liberal financial system enhances economic growth. This school of thought is classified as supply-led theory of finance-growth nexus. While $t$ it is generally believed that a well-functioning financial sector is a precondition for the efficient allocation of resources and the exploitation of an economy's growth potential, however, there is a possibility of dual causality. This, invariably, culminated in the emergence of demand-led theory of finance-growth nexus. Recent developments in some economies around the world seem to provide support for this school of thought.

\section{Shaw (1973) Hypothesis}

This theory states that financial liberalization and stock market development would promote economic growth through their effects on the growth rate of savings, investment, and thus economic growth. Shaw (1973) argued that the repressed financial markets (low and administered interest rates, domestic credit controls, high reserve requirements and concessional credit practices) discourages savings, retards the efficient allocation resources, increases the segmentation of financial markets, constrains investment and in term lowers the economic growth rate. This idea was adopted by great international institutions such as the International Monetary Fund (IMF) and the World Bank (Bouzid, 2012).

\section{The Modern Growth Theory}

The banking system through their function of financial intermediation plays a vital role in economic growth of both developed and developing economies. Financial intermediation is the process in which financial institutions particularly commercial banks mobilize money from surplus economic units in the form of savings and channel such funds to the deficit units or sectors of the economy who are in need of funds to carryout useful economic activities. The 
success of the financial liberalization process depends to the following hypothesis: the effective deepening of the financial sector, a positive correlation and a perf2.3ect complementarity between the money demand and investment (Bouzid, 2012). From the view of an underdeveloped economy, the expansion of bank credit offering more financial resources to industries in one of the contributory causes for greater economic development.

\section{CONCEPTUAL FRAMEWORK}

Capital markets is about providing essential long time finance for economic activities. It's a venue where investors source for fund and sell proportion of their share holding for liquidity requirement in emergency. It aids wealth distribution and making capital safer for investors. Capital markets can create greater financial inclusion by introducing new products and services tailored to suit investors' preference for risk and return as well as borrowers' project needs and risk appetite. Innovation, credit counseling, financial education and proper segment identification constitute the possible strategies to achieve this. A well-developed capital market creates a sustainable low-cost distribution mechanism for multiple financial products and services across the country.

In most developing countries, capital market has fallen short of expectations in spite of the great potentials for financing development and at times had to be supported by domestic soft loans or substituted by bank credit.

Figure 1, depicts the expected relationship between all variables of the study. Total Bank Credit (Banks) and Market Capitalization (Stock Market) on Economic Growth and Development (GDP). In Nigeria for example, the capital market could not meet the challenge of mobilizing savings for development because it was lacking in liquidity which leaves some gaps for banks to fill. Hence, a well functional banking sector is a necessary condition for economic growth. To this end, the role of the banking sector and stock market in boosting the economic growth and the inter play within the two agents of Nigeria economy shall be examined.

Figure 1. The relationship between the variables of the study. INDEPENDENT VARIABLES

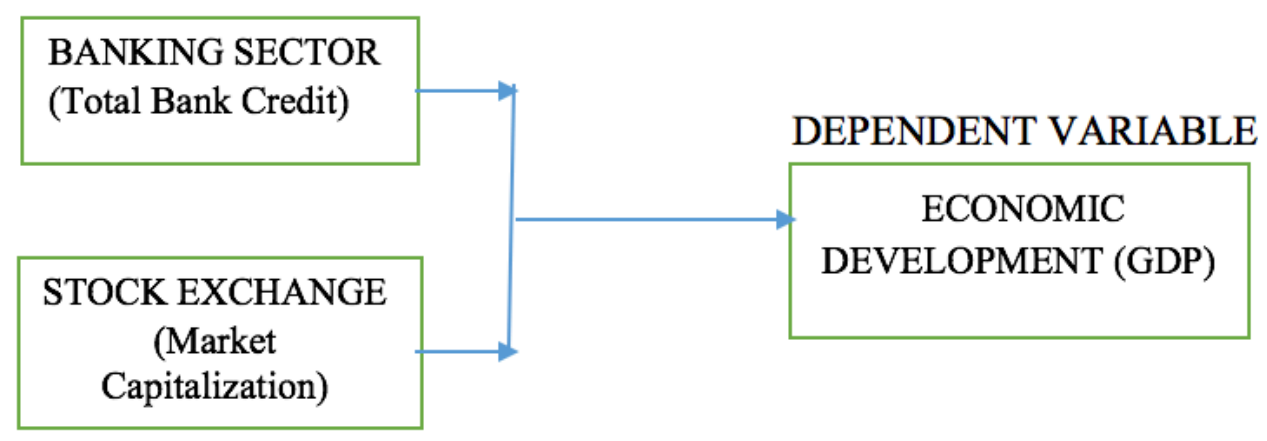

EMPIRICAL REVIEW

A wide range of securities are offered for sale in the stock market. This enable brokers and investors to pool fund and exchange risks with price tag. The essence of the stock market is to raise medium and long terms finance through assets with attractive yields, liquidity and risk characteristics, it encourages saving in financial form (Akingbohungbe, 1996). Because of their role in the market economy, the capital market occupies an important place, through their specific mechanisms. The stock market has helped government and corporate entities to raise long term capital for financing new projects, and expanding and modernizing industrial/commercial concerns, Al-Faki (2006). 
Capital market enhances economic growth and development. Countries with well-developed capital markets experience higher economic growth than countries without, Nwankwo (1999). Evidence indicates that, while most capital markets in African countries are relatively underdeveloped, those countries which introduced reforms that are geared towards development of capital markets have been able to grow at relatively higher and sustainable rates.

South Africa, the country whose capital market is the largest and most developed in Africa, in terms of market capitalization and trading volume, has average per capita real GDP of $3.2 \%$ over the last 8 years. Countries like Egypt, Ghana, Tanzania, Botswana and Mauritius, whose capital markets have been developing recently, were able to realize average per capita growth rates of around $2.8 \%$ for the same period (8 years). However, some economies which did not have formal or effective capital market like Lesotho, Seychelles and Ethiopia could not manage to realize average per capita growth rates above $2.7 \%$ over the past 8 years. Even those countries with small and less developed capital market like Swaziland and Uganda did not manage to realize average per capita growth rates above $2.7 \%$ during the past 8 years (CBL Economic Review, August 2009, No. 109).

According to African Securities Exchanges Association (ASEA), the combined value of all of the equity securities traded in respect of the 21 ASEA member stock exchanges that were reviewed by KPMG during 2013 amounted to US $\$ 454974.4$ million. The total market capitalisation of the reviewed ASEA Members was US\$1 611.80 billion to which the JSE contributes US\$1 102.3 billion. Excluding the JSE, the Namibian Stock Exchange has the highest market capitalisation, amounting to US $\$ 134.1$ billion, followed by the Nigerian Stock Exchange, with a market capitalisation of US $\$ 80.7$ billion. The total number of listed companies on the 21 ASEA member stock exchanges was 1413 as at 31 December 2013. The African stock exchanges have amongst the lowest liquidities in the world (ASEA 2014 Yearbook).

The banking sectors of a number of sub-Saharan African (SSA) countries have exhibited significant growth in recent years. Banking industries across SSA are highly concentrated, with the top four banks usually accounting for the majority of total banking sector assets within a particular country. The growing presence of subsidiaries of major global banks on the continent has obviously improved the availability and quality of financial services in recent years. Presently, the international banks with the largest footprints across Africa originate mostly from the United Kingdom (UK), France and the United States. Their focus is on high margin corporate businesses as opposed to the growing retail banking and financial inclusion for lower income households.

Large banks from well-developed financial markets on the African continent have in fact made the great impact. As a result, financial sectors across the continent benefitted from gains in efficiency, innovation and financial deepening. Some of the larger African banks include; Ecobank (with its roots in Togo) that has the biggest presence in Africa and rendering banking services in 32 countries by 2013, the United Bank for Africa (domiciled in Nigeria) that operates in 19 countries across Africa, Standard Bank who has a comprehensive presence within 18 African countries and, Barclays Africa Group that delivered banking services in 10 African countries by 2013 including through the Absa brand in South Africa. Despite strong banking sector growth, however, a large proportion of the African populace still does not make use of formal financial services. To this end, banks operating on the continent have started to explore alternative operating models, including mobile and online banking, mobile branches and using third-party agents, such as supermarkets, post offices even ordinary shops and stores. 


\section{RESEARCH METHODOLOGY}

The development of financial market and its impact on economic growth of the different African countries will be examined. These countries are Nigeria in West Africa, Kenya in East Africa and Johannesburg in South Africa. These countries were selected because they are central to economic development in their respective axis.

Study variables shall include those essential indicators of performance on financial system and economic development, such as Stock Market Capitalization, Total Bank Credit and Real Gross Domestic Product. This study shall rely on secondary data sourced majorly from government own institutions like the Central Bank, Stock Exchanges and other relevant Government publications.

After diagnostics analysis and data cleansing, tests and data analysis will be done using panel data through multiple regression by OLS using Stata programme.

\section{Model Specification}

The contributions of the Banking sector in term of total credit provision or total loan portfolio for the economic development of African state will be examined. Also the relevance of capital markets especially the stock exchange in capital formation by raising necessary fund for listed companies thereby fostering economic development will be considered.

where;

$$
\mathrm{RGDP}=\mathrm{f}(\mathrm{TBC}+\mathrm{MC})
$$

RGDP = Real Gross Domestic Product

$\mathrm{TBC}=$ Total Bank Credit and

MC = Market Capitalisation.

Correlation analysis was carried out to measure the inter-relationship between independent variables and dependent variables. Correlation measures the size and direction of the relationship between two variables (Tabachnick and Fidell, 2001). In addition, a regression analysis was conducted in order to further evaluate and understand the relationships between the dependent and independent variables of the study. The two basic types of regression are linear regression and multiple regressions. Linear regression uses one independent variable to explain and/or predict the outcome of $\mathrm{Y}$, while multiple regressions use two or more independent variables to predict the outcome.

Regression takes a group of random variables, thought to be predicting $\mathrm{Y}$, and tries to find a mathematical relationship between them. This relationship is typically in the form of a straight line (linear regression) that best approximates all the individual data points. In multiple regressions the separate variables are differentiated by using subscripted numbers.

$$
\text { Regression equation: } Y=\beta 0+\beta 1 X 1+\beta 2 X 2+\varepsilon(2)
$$

Where:

$\mathrm{Y}=$ the variable that we are trying to predict (Economic Development);

$\mathrm{X} 1, \mathrm{X} 2$, = the variable that used to predict $\mathrm{Y}$;

$\beta 0=$ Constant Term;

$\beta 1, \beta 2$, = Beta coefficients;

$\varepsilon=$ Error Term.

In this study, regression is used to determine how specific factors such as the total bank credit and market capitalization influence the economic development of African state. 


\section{Hausman test}

\begin{tabular}{|c|c|c|c|c|}
\hline & \multicolumn{2}{|c|}{ Coefficients -} & \multirow{3}{*}{$\begin{array}{c}(\mathrm{b}-\mathrm{B}) \\
\text { Difference }\end{array}$} & \multirow{3}{*}{$\begin{array}{c}\operatorname{sqrt}\left(\operatorname{diag}\left(V_{-} b_{-}-V_{-} B\right)\right. \\
\text { S.E. }\end{array}$} \\
\hline & (b) & (B) & & \\
\hline & fixed & random & & \\
\hline tbc & -13.95866 & -32.44954 & 18.49088 & 6.802276 \\
\hline $\mathrm{mc}$ & 10.81195 & 19.75471 & -8.94276 & . \\
\hline
\end{tabular}

$\mathrm{b}=$ consistent under $\mathrm{Ho}$ and $\mathrm{Ha}$; obtained from xtreg

$\mathrm{B}=$ inconsistent under Ha, efficient under Ho; obtained from xtreg

Test: Ho: difference in coefficients not systematic

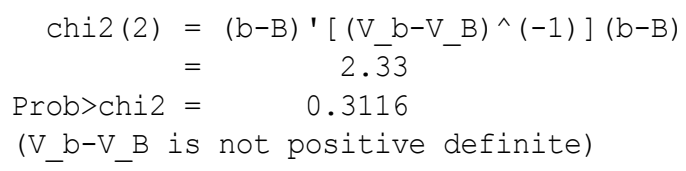

Since prob $>$ chi2 is greater than 0.05 , we use random effects

\section{Individual country's Data Analysis and Result}

\section{(a) NIGERIA}

\section{Model Summary}

\begin{tabular}{|c|c|c|c|c|}
\hline Model & $\mathrm{R}$ & $\mathrm{R}$ Square & $\begin{array}{c}\text { Adjusted R } \\
\text { Square }\end{array}$ & $\begin{array}{c}\text { Std. Error of the } \\
\text { Estimate }\end{array}$ \\
\hline 1 & $.899^{\mathrm{a}}$ & .807 & .615 & 12.86384 \\
\hline
\end{tabular}

a. Predictors: (Constant), mc, tbc

The model fits the data by $80.7 \%$.

ANOVA $^{\mathrm{a}}$

\begin{tabular}{|ll|c|c|c|c|c|}
\hline Model & & Sum of Squares & Df & Mean Square & F & Sig. \\
\hline \multirow{4}{*}{1} & Regression & 1386.543 & 2 & 693.272 & 4.189 & $.013^{\mathrm{b}}$ \\
& Residual & 330.957 & 2 & 165.478 & & \\
& Total & 1717.500 & 4 & & & \\
\hline
\end{tabular}

a. Dependent Variable: gdp

b. Predictors: (Constant), mc, tbc

The overall model is significant

Coefficients $^{\mathbf{a}}$

\begin{tabular}{|c|c|c|c|c|c|c|}
\hline \multirow{2}{*}{\multicolumn{2}{|c|}{ Model }} & \multicolumn{2}{|c|}{ Unstandardized Coefficients } & \multirow{2}{*}{$\begin{array}{c}\begin{array}{c}\text { Standardized } \\
\text { Coefficients }\end{array} \\
\text { Beta }\end{array}$} & \multirow[t]{2}{*}{$\mathrm{T}$} & \multirow[t]{2}{*}{ Sig. } \\
\hline & & B & Std. Error & & & \\
\hline \multirow{3}{*}{1} & (Constant) & 60.298 & 16.954 & & 3.369 & .018 \\
\hline & Tbc & -9.505 & 3.829 & -1.926 & -2.482 & .031 \\
\hline & Mc & 5.686 & 2.172 & 1.977 & 2.617 & .020 \\
\hline
\end{tabular}

a. Dependent Variable: gdp

Tbc and mc are significant 
(b) KENYA

Model Summary

\begin{tabular}{|c|c|c|c|c|}
\hline Model & $\mathrm{R}$ & $\mathrm{R}$ Square & $\begin{array}{c}\text { Adjusted R } \\
\text { Square }\end{array}$ & $\begin{array}{c}\text { Std. Error of the } \\
\text { Estimate }\end{array}$ \\
\hline 1 & $.794^{\mathrm{a}}$ & .630 & .559 & 68.3213442028 \\
\hline
\end{tabular}

a. Predictors: (Constant), mc, tbc

\begin{tabular}{|cl|c|c|c|c|c|}
\hline \multicolumn{1}{|c|}{} & \multicolumn{1}{c|}{ ANOVA $^{\mathrm{a}}$} \\
\hline \multirow{4}{*}{1} & Sum of Squares & Df & Mean Square & F & Sig. \\
\cline { 2 - 7 } & Regression & 15874.333 & 2 & 7937.166 & 6.700 & $.009 \mathrm{~b}$ \\
& Residual & 9335.612 & 2 & 4667.806 & & \\
& Total & 25209.945 & 4 & & & \\
\hline
\end{tabular}

a. Dependent Variable: gdp

b. Predictors: (Constant), mc, tbc

The overall model is significant

Coefficients ${ }^{\mathrm{a}}$

\begin{tabular}{|c|c|c|c|c|c|c|}
\hline \multirow{2}{*}{\multicolumn{2}{|c|}{ Model }} & \multicolumn{2}{|c|}{ Unstandardized Coefficients } & \multirow{2}{*}{$\begin{array}{c}\begin{array}{c}\text { Standardized } \\
\text { Coefficients }\end{array} \\
\text { Beta }\end{array}$} & \multirow[t]{2}{*}{$\mathrm{T}$} & \multirow[t]{2}{*}{ Sig. } \\
\hline & & $\mathrm{B}$ & Std. Error & & & \\
\hline \multirow{3}{*}{1} & (Constant) & -21.301 & 84.786 & & -3.552 & .037 \\
\hline & Tbc & 32.689 & 47.358 & 1.458 & .690 & .561 \\
\hline & Mc & 49.705 & 30.416 & 3.085 & 2.634 & .044 \\
\hline
\end{tabular}

a. Dependent Variable: gdp

Tbc is insignificant while mc is significant

(c) JOHANNESBURG

Model Summary

\begin{tabular}{|c|c|c|c|c|}
\hline Model & $\mathrm{R}$ & R Square & $\begin{array}{c}\text { Adjusted R } \\
\text { Square }\end{array}$ & $\begin{array}{c}\text { Std. Error of the } \\
\text { Estimate }\end{array}$ \\
\hline 1 & $.934^{\mathrm{a}}$ & .873 & .745 & 15.11601 \\
\hline
\end{tabular}

a. Predictors: (Constant), mc, tbc

The model perfectly fits the data. $87.3 \%$

ANOVAa

\begin{tabular}{|ll|c|c|c|c|c|}
\hline Model & & Sum of Squares & Df & Mean Square & F & Sig. \\
\hline \multirow{4}{*}{1} & Regression & 3130.453 & 2 & 1565.226 & 6.850 & $.007^{\mathrm{b}}$ \\
& Residual & 456.987 & 2 & 228.494 & & \\
& Total & 3587.440 & 4 & & & \\
\hline
\end{tabular}

a. Dependent Variable: gdp

b. Predictors: (Constant), mc, tbc

The overall model is significant

Coefficients $^{\mathbf{a}}$

\begin{tabular}{|c|c|c|c|c|c|c|}
\hline \multirow{2}{*}{\multicolumn{2}{|c|}{ Model }} & \multicolumn{2}{|c|}{ Unstandardized Coefficients } & \multirow{2}{*}{$\begin{array}{c}\begin{array}{c}\text { Standardized } \\
\text { Coefficients }\end{array} \\
\text { Beta }\end{array}$} & \multirow[t]{2}{*}{$\mathrm{T}$} & \multirow[t]{2}{*}{ Sig. } \\
\hline & & B & Std. Error & & & \\
\hline \multirow{3}{*}{1} & (Constant) & 83.009 & 56.862 & & 3.408 & .013 \\
\hline & Tbc & 23.303 & 36.718 & 1.190 & 2.635 & .042 \\
\hline & Mc & 12.643 & 3.700 & 3.022 & 3.417 & .026 \\
\hline
\end{tabular}

a. Dependent Variable: gdp

Tbc and mc are significant $\mathrm{Gdp}=83.00+23.30 \mathrm{Tbc}+12.64 \mathrm{Mc}+$ error term 


\section{DISCUSSION OF RESULT AND FINDINGS}

Economic growth generally is a function of efficient and effective financial sector that pools domestic savings and mobilizes capital for productive projects especially in modern day economy. Absence of effective capital market and dynamic banking sector could leave most productive projects which carry developmental agenda unexploited. Financial markets connect the monetary sector with the production and services providers and therefore facilitates economic growth.

Evidence from general regression analysis on the three sampled countries Gross Domestic Product and their financial system, showed that both Total Bank Credit and Stock Market Capitalization affect African countries Gross Domestic Product (Gdp = 843.03 -32.45tbc + $19.75 \mathrm{mc}+$ error). This concurred with Levine and Zervos (1998) who found evidence that stock market liquidity and banking development have a positive relationship with economic growth.

For individual countries (Nigeria, Kenya and South Africa), the financial system has impact on GDP in varying degrees:

In Nigeria, Tbc and Mc are significant as Gdp $=60.30-9.50 \mathrm{Tbc}+5.70 \mathrm{Mc}+$ error term

In Kenya, Tbc is insignificant while Mc is significant as $\mathrm{Gdp}=21.30+32.70 \mathrm{Tbc}+49.70 \mathrm{Mc}+$ error term

In South Africa, Tbc and Mc are significant as Gdp $=83.00+23.30 \mathrm{Tbc}+12.64 \mathrm{Mc}+$ error term From the above result Kenya can benefit from dynamic culture of Banking in Nigeria and South Africa. Nigeria and Kenya can benefit from stable Capital Market performance in South Africa and of course Nigeria and South Africa can take advantage of available market in Kenya. This collaboration can be extended to cover all African countries for an all embracing economic development through financial system.

\section{CONCLUSION}

Just like a well-developed financial market can spring ball a nation economic development, lack of it would be a particularly serious disadvantage for any economy. Equity, liquidity and management competence is essential for the emergence and growth of innovative firms. The contribution of financial markets is a necessity for maintaining the competitiveness of an economy today given the strongly increased international competition, rapid technological progress and the increased role of innovation for growth performance.

Bank-based finance has a special role to play for many companies in need of funds, and thus helps to ensure a well-balanced growth process. Economies that have both well-developed banking sectors and capital markets thus have essential pre-requisite for economic development and thus at an advantage. The banking sectors of most African countries, however, do not yet have sufficient depth to play a catalytic role in promoting the development of a deep financial sector. Most standard indicators of banking sector depth are low compared to the rest of the world, credit to the private sector is limited (Duisenberg W. F, 2001).

The African stock exchanges have amongst the lowest liquidities in the world. The lack of liquidity on the African stock exchanges is due to a number of factors including the limited number of listed companies on the stock exchanges, the limited free float, the low numbers of retail investors and the high transaction costs. Normally developing efficient financial markets and achieving deep and efficient financial markets will likely be difficult in the absence of corresponding policies that promote economic stability and stimulate investor confidence, 
while transparent macroeconomic management and general political stability is necessary to attract investment. To date, both banking sector and capital market development have been constrained by relatively weak regimes. Stronger legal structures and regulatory bodies to better define property rights, enforce contracts and protect investors are needed before financial systems can operate effectively. This suggests that some countries may be too small to develop viable capital markets, leading to calls for regional capital and money markets to help overcome scale constraints.

In Kenya, the financial sector is regulated by the Retirement Benefits Authority, the Insurance Regulatory Authority, the Capital Markets Authority, the Central Bank, and the Savings and Credit Cooperative Societies Regulatory Authority, and work is under way to create a financial services "super regulator. Kenya's financial sector has grown significantly and is integrated into the regional and international economy. Its subsectors include banking, capital markets, insurance, pensions, safety nets, and resolution institutions (such as the Kenya Deposit Insurance Corporation), financial markets infrastructure (such as the Nairobi Securities Exchange, stock brokers, and rating agencies), and savings and credit cooperatives. The total value of assets held by banks, pensions, insurance, and credit cooperatives accounted for 98percent of the value of GDP in 2013, up from 96percent of total assets excluding capital markets in 2012. The total value of equity market capitalization amounted to 51percent of GDP in 2013, though banking dominates the financial sector, accounting for 71percent of total assets. Kenyan economy because of its size and relationship with other east Africa countries' financial system is warming up to becoming a regional financial hub. This is a key strategic objective for the government, as articulated in her Vision 2030. Several Kenyan companies have cross-listed in Tanzania and Uganda, and the three exchanges have also established a common Securities Regulatory Authority and initiated a joint automated trading platform.

In Nigeria, the Commercial banks are the most relevant financial institutions in Nigeria to channel savings into productive investment units. The banking sector also showed stronger capacity to finance real sector activities with substantial credit flow to the core private sector as CP/GDP ratio increased from $16.9 \%$ in 2011 to $19.2 \%$ in 2014. In addition, the increased use of the various electronic money products reflected the shift away from cash transactions. According to the Central Bank of Nigeria statistical bulletin 2014, the depth of the financial sector showed some significant improvements. Despite these improvements the Nigeria's economic growth has been dwindling and has still remained fragile not strong enough to significantly reduce the prevailing level of poverty. Though the various indicators used in measuring financial development has been increasing steadily over the years. The link between the financial sector and the growth of the economy has been weak. The real sector of the economy, most especially the high priority sectors which are also said to be economic growth drivers are not effectively and efficiently serviced by the financial sector as posit by (Beck, 2011; Beck, 2013). The banks are declaring billions of profit but yet the real sector continues to be weak thereby reducing the productivity level of the economy. Most of the operators in the productive sector are folding up due to the inability to get loan from the financial institutions or the cost of borrowing was too outrageous. The Nigerian banks have concentrated on short term lending as against the long term investment which should have formed the bedrock of a virile economic transformation.

In South Africa, the Johannesburg Stock Exchange (JSE) is a giant. It is the largest exchange in Africa and among the top twenty largest in the world in terms of market capitalisation. The JSE has evolved from a traditional floor based equities trading market to a modern securities exchange providing fully electronic trading, clearing and settlement in equities, financial and agricultural derivatives and other associated instruments. It has technical agreement with the 
London Stock Exchange (LSE) which enables dual primary listings on both exchanges since 2001. This contributed to the South African economy becoming an active hub of activity where expansion is encouraged, businesses are enhanced, performance is driven and shareholder value is created. As the gateway to Africa's economy, the JSE provides the link between international markets and the continent. In 2008, a daily average of 334 million shares was traded on the JSE. At year-end, there were 992 listed securities on the JSE with a total market capitalisation of R4,514 billion compared to R5,696 billion in 2007.

\section{RECOMMENDATIONS}

Financial institutions, economy and markets may grow simultaneously. In East Africa, national stock markets have established a common Securities Regulatory Authority and initiated a joint automated trading platform. Such efforts should be encouraged more widely alongside strategies to strengthen legal frameworks as constructive steps to help develop financial markets in Africa.

However, establishing common functional regional exchanges, Securities Regulatory Authority and a joint automated trading platform is complex. It requires significant technological investment and the surmounting of non-trivial administrative and political barriers. For example, participating countries need to harmonise their trading systems, legal regulations, reporting standards and taxation schemes. Stock markets are also potent national symbols therefore political resistance may arise in countries joining a regional exchange based elsewhere. The launch of regional exchanges may thus be unrealistic in the short term but smaller exchanges may profit by capitalising on existing systems of more advanced exchanges in their region. Such efforts include cross-listing stocks, harmonising listing requirements and regulations, and jointly using automated systems.

The advent of various Bassel agreement has already forged some collaboration within the global financial institutions especially banks. This can be consolidated by encouraging multinational mega banks across the African state like (Eco bank) for member countries economic development. But similar problems as discussed under capital market must also be sorted out.

\section{References}

Akingbohungbe, S.S. (1996). The role of the financial sector in the development of the Nigerian economy. Paper presented at a workshop organized by Center for African Law and Development Studies.

Al-faki M. (2006). The Nigerian capital market and socio-economic development. A paper presented at the 4th distinguished Faculty of Social Science, Public Lectures, University of Benin, 9-16

Arcand, J.-L., Berkes, E., Panizza, U., (2012). “Too Much Finance?”, IMF Working Paper No 12/161.

ASEA Yearbook (2014). The ASEAN Secretariat Jakarta.

Beck, T., Demirguc-Kunt, A., Levine, R., 2009. Financial Institutions and Markets Across Countries and Over Time: Data and Analysis, World Bank, Policy Research Working Paper 4943. /

Beck, T., Fuchs, M., Uy, M., 2009. Finance in Africa: Achievements and Challenges, World Bank, Policy Research Working Paper 5020.

Beck, T. H. L. (2011). The Role of Finance in Economic Development: Benefits, Risks, and Politics. (EBC Discussion Paper; Vol. 2011-038). Tilburg: EBC.

Beck, T., Demirgüç-Kunt, A, Honohan, P (2009) Access to Financial Services: Measurement, Impact and Policies

Beck, T., (2012). Finance and Growth: Lessons from the Literature and the Recent Crisis. Prepared for the LSE Growth Commission.

Beck Thorsten (2013). Bank Financing for SMEs - Lessons from the Literature, National Institute Economic Review, Volume: 225 issue: 1, pp 23-38 
Bouzid A (2012). The Relationship of Oil Prices and Economic Growth in Tunisia: A Vector Error Correction Model Analysis, Romanian Economic Journal, 2012, vol. 15 (43).

Blommestein, H., Horman, G., (2007). Government Debt Management and Bond Markets in Africa, Financial Market Trends 1, 241-73.

CBL Economic Review (2009). Importance of Capital Market as an instrument of Economic Development. Central Bank of Lesotho. August 2009, No. 109.

Duisenberg, W. F. (2001). The role of financial markets for economic growth, Speech delivered by Dr. Willem F. Duisenberg, at the Economics Conference "The Single Financial Market: Two Years into EMU" organised by the Oesterreichische National bank in Vienna on 31 May 2001

Kargi, H. S. (2011). Credit Risk and the Performance of Nigerian Banks, Ahmadu Bello University, Zaria

Lardy, Nicholas R.,(1998). China's Unfinished Economic Revolution, Brookings Institution Press, Washington, D.C. Levine Ross and Zervos Sara (1998). Stock Markets, Banks, and Economic Growth. The American Economic Review, Vol. 88, No. 3. pp. 537-558.

Nwankwo G.O. (1999). "Money and capital market in Nigeria today". Lagos: University of Lagos Press.

Schumpeter, J., (1982). "The Theory of Economic Development”. New Jersey: Transaction Publishers.

Shan, J.Z., F. Sun and A. Morris, (2001). Financial development and economic growth. Review of International Economics 9, 443-454.

Shaw, E. S. (1973). Financial Deepening and Economic Development .New York Oxford

Tabachnick, B. G. \& Fidell, L. S. (2007). Using multivariate statistics (5th ed.). Upper Saddle River, NJ: Pearson Allyn \& Bacon. 